\title{
Soluble CD30 is a new biomarker to predict two-year overall survival of adult $\mathrm{T}$ cell leukemia/lymphoma patients
}

\author{
Ratiorn Pornkuna ${ }^{1,2}$, Shigeki Takemoto ${ }^{1,2,3^{*}}$, Michihiro Hidaka ${ }^{2,3}$, Yoshio Haga ${ }^{1,2}$ \\ From 16th International Conference on Human Retroviruses: HTLV and Related Viruses \\ Montreal, Canada. 26-30 June 2013
}

\section{Introduction}

Adult T-cell leukemia/lymphoma (ATLL) caused by human retrovirus, HTLV-1, is a neoplasm of mature T-cell. In Japan, more than a thousand patients with ATLL die every year incurable with median survival time less than one year. We aim to investigate clinical value of soluble $\mathrm{CD} 30$ (sCD30) levels in sera on prediction of short term mortality and overall survival (OS) in ATLL patients.

\section{Methods}

Between September 2005 and December 2010, a prospective cohort study was done in 60 ATLL patients treated with chemotherapy or allogeneic hematopoietic stem cell transplantation (HSCT) at the Department of Hematology, National Hospital Organization Kumamoto Medical Center, Japan. Univariate analysis of OS was performed using the Kaplan-Meier method to estimate survival probabilities in patient subgroups, and the log-rank test was used for statistical comparisons.

\section{Results}

In the patients undergoing chemotherapy, pre-treatment status of BUN, creatinine, AST, ALT ALP, total bilirubin, $\mathrm{LDH}$, serum albumin, corrected calcium, platelet, percentage of malignant cells in peripheral blood, serum SCD30 level, serum soluble IL-2 receptor level, performance status and Charlson's comorbidity index were the risk factors of two-year OS. In patients undergoing HSCT, pre-treatment status of source of stem cells, HLA matching, BUN, $\mathrm{LDH}$, corrected calcium, CRP, serum sCD30 level, and

\footnotetext{
* Correspondence: takemotoratiorn@gmail.com

'Department of International Medical Cooperation, Graduate School of

Medical Sciences, Kumamoto University, Kumamoto, Japan

Full list of author information is available at the end of the article
}

Charlson's comorbidity index were the significant risk factors of two-year OS. Our result suggested that sCD30 was the common significant risk factor of chemotherapy and HSCT in two-year OS.

\section{Conclusion}

sCD30 may be a new biomarker for newly-diagnosed ATLL. The combination of various factors can provide useful information of OS prediction.

\section{Authors' details}

'Department of International Medical Cooperation, Graduate School of Medical Sciences, Kumamoto University, Kumamoto, Japan. ${ }^{2}$ Institute for Clinical Research, National Hospital Organization Kumamoto Medical Center, Kumamoto, Japan. ${ }^{3}$ Department of Hematology, National Hospital

Organization Kumamoto Medical Center, Kumamoto, Japan.

Published: 7 January 2014

\section{doi:10.1186/1742-4690-11-S1-P2}

Cite this article as: Pornkuna et al: Soluble CD30 is a new biomarker to predict two-year overall survival of adult T cell leukemia/lymphoma patients. Retrovirology 2014 11(Suppl 1):P2.

Submit your next manuscript to BioMed Central and take full advantage of:

- Convenient online submission

- Thorough peer review

- No space constraints or color figure charges

- Immediate publication on acceptance

- Inclusion in PubMed, CAS, Scopus and Google Scholar

- Research which is freely available for redistribution

Submit your manuscript at www.biomedcentral.com/submit 